Рекомендована д. фрармац. наук, профр. Д. І. Дмитрієвським

УДК 615.31-021.633:[615.31:615.214]+615.31'792]:615.453.6.012/.014

DOI 10.11603/2312-0967.2017.3.8117

\title{
ВИБІР ДОПОМІЖНИХ РЕЧОВИН 3 МЕТОЮ ОТРИМАННЯ ТАБЛЕТОК НА ОСНОВІ КАРБАМАЗЕПІНУ 3 ТІОТРИАЗОЛІНОМ МЕТОДОМ ВОЛОГОЇ ГРАНУЛЯЦІї
}

\author{
() Л. І. Кучеренко ${ }^{1,2}$, Г. Р. Німенко², 3. Б. Моряк² \\ НВО «Фарматрон» ${ }^{1}$ \\ Запорізький державний медичний університет² \\ farm_chem@bigmir.net
}

\begin{abstract}
Мета роботи. Вивчення впливу допоміжних речовин (ДР) на фрармако-технологічні показники таблеток карбамазепіну 3 тіотриазоліном, отриманих методом вологої грануляції. Вибір кращих ДР для отримання оптимального складу таблеток карбамазепіну з тіотриазоліном.

Матеріали і методи. Лікарські речовини - карбамазепін і тіотриазолін (1,5:1), ДР (наповнювачі, розпушувачі, зв'язуючі, змазуючі). Таблетки виготовляли методом вологої грануляції. Вплив ДР речовин на таблетки карбамазепіну з тіотриазоліном вивчали за такими показниками: стійкість до роздавлювання, стираність, розпадання, зовнішній вигляд поверхні після 6-місячного зберігання.

Результати й обговорення. За результатами дисперсійного аналізу експериментальних даних встановлено, що на стійкість таблеток карбамазепіну з тіотриазоліном до роздавлювання, стираність, розпадання, зовнішній вигляд поверхні після 6-місячного зберігання впливає природа наповнювача, розпушувача, зв'язуючих та змазуючих ДР. Так, на стійкість таблеток до роздавлювання серед наповнювачів найкращий вплив має лактоза моногідрат, серед розпушувачів лідером є кросповідон ХЛ 10, серед зв'язуючих - 2 \% розчин МЦ, серед змазуючих речовин - натрій лаурилсульсрат.

Найменша стираність таблеток карбамазепіну з тіотриазоліном спостерігається при використанні в якості наповнювача МКЦ 101, розпушувача - кросповідону ХЛ 10, зв'язуючих - 2 \% розчин МЦ, змазуючих - кальцію стеарат.

Найшвидше розпадалися таблетки карбамазепіну 3 тіотриазоліном при використанні в якості розпушувача натрій кроскармелози, змазуючої речовини - магнію стеарату та зв'язуючої речовини - крохмального клейстеру. Наповнювачі не відрізняються між собою за впливом на час розпадання таблеток кабамазепіну 3 тіотриазоліном. Крохмаль картопляний та кислота стеаринова найбільшою мірою забезпечують збереження кольору поверхні таблеток карбамазепіну з тіотриазоліном після 6-ти місяців зберігання. Вивчені наповнювачі та зв'язуючі речовини однаковою мірою впливають на вказаний показник.

Висновки. Вивчено вплив 16-ти допоміжних речовин на фрармако-технологічні властивості (стійкість до роздавлювання, стираність, розпадання, зовнішній вигляд поверхні після 6-ти місяців зберігання) таблеток карбамазепіну з тіотриазоліном. За сукупністю вивчених показників відібрані кращі поєднання ДР для подальшого вивчення з метою розробки оптимального складу та технології таблеток карбамазепіну з тіотриазоліном.
\end{abstract}

Ключові слова: карбамазепін, тіотриазолін; таблетки; допоміжні речовини; метод вологої грануляції; математичне планування експерименту.

Повідомлення 2. Вплив допоміжних речовин на фрармако-технологічні властивості таблеток карбамазепіну з тіотриазоліном, отриманих методом вологої грануляції.

Вступ. Епілепсія займає третє місце серед різноманіття форм патологій центральної нервової системи (ЦНС). У зв'язку з цим створення нових безпечних лікарських засобів на основі комбінацій протиепілептичного препарату 3 антиоксидантами, завдяки чому зменшиться велика кількість побічних ефектів та стане можливим розширення застосування нового препарату, є одним 3 головних завдань сучасної фрармації. Виходячи $з$ цього, нами був розроблений та ство- рений комбінований лікарський засіб на основі карбамазепіну з тіотриазоліном у оптимальному співвідношенні 1,5:1. Саме при використанні комбінації таких діючих речовин та у такому співвідношенні побічні ефректи карбамазепіну зменшилися, а деякі взагалі зникли, також слід відзначити, що на це вплинув один з сучасних, потужних антиоксидантів - тіотриазолін [1-3].

У попередніх дослідженнях ми обґрунтували доцільность створення комбінованого лікарського засобу на основі карбамазепіну 3 тіотриазоліном під умовною назвою «Карбатрил». Було вивчено вплив допоміжних речовин (ДР) на процес пресування, 30-

ISSN 2312-0967. Pharmaceutical review. 2017. № 3 
Фармацевтична технологія, біофармація, гомеопатія Pharmaceutical technology, biopharmacy, homeopathy

внішній вигляд і однорідність дозування таблеток карбамазепіну з тіотриазоліном [4].

Метою цього дослідження $є$ вивчення впливу ДР на фрармако-технологічні показники таблеток карбамазепіну з тіотриазоліном, отриманих методом вологої грануляції. Вибір кращих ДР для отримання оптимального складу таблеток кармазепіну з тіотриазоліHOM.

Матеріали і методи. Як було зазначено в попередніх дослідженнях, при створенні таблеток карбамазепіну з тіотриазоліном враховувались фрізико-хімічні і технологічні властивості діючих речовин, їх співвідношення в складі таблеток, середню масу таблеток [4]. Для тіотриазоліну характерне пряме пресування завдяки технологічним властивостям порошку. Карбамазепін, у свою чергу, належить до дрібнодисперсних порошків, з яких можна отримати таблетки тільки з використанням методу вологої грануляції. Враховуючи все вище зазначене ми прийняли рішення використовувати метод вологої грануляції для отримання таблеток «Карбатрил». В дослідженні використано: карбамазепін (виробник: Jubilant Organosys Ltd, IHдія, серія 130223342); тіотриазолін (виробник: Державне підприємство «Завод хімічних реактивів» Науково-технологічного комплексу «Інститут монокристалів» НАН України, серія 2341112). Для отримання таблеток велику увагу приділяють вибору раціональних допоміжних речовин (ДР), які використовуються при вологій грануляції: наповнювачі, розпушувачі, зв'язуючі, змазуючі [5]. Допоміжні речовини повинні забезпечувати виконання певних фрармако-технологічних вимог, які висуває ДФУ до таблеток [6].

У процесі роботи було вивчено чотири групи допоміжних речовин, які наведено в таблиці 1.

У роботі використовували сертифріковані допоміжні речовини як вітчизняного, так і закордонного виробництва.
Таблетки карбамазепіну з тіотриазоліном готували за класичною схемою, для отримання таблеток методом вологої грануляції, яка була наведена в попередній роботі [4].

Для вивчення чотирьох якісних фракторів використовували греко-латинський квадрат 4х4 [7]. Матрицю планування експерименту та результати дослідження срармако-технологічних властивостей таблеток карбапмазепіну з тіотриазоліном наведено в таблиці 2.

Результати й обговорення. В лабораторних умовах були виготовлені 16 серій таблеток «Карбатрил» методом вологої грануляції. Кожна серія дослідів реалізована у двох послідовностях. Отримані таблетки «Карбатрил» досліджували на стійкість до роздавлювання, стираність, час розпадання та зовнішній вигляд поверхні після 6-ти місяців зберігання. Результати досліджень підлягали дисперсійному аналізу за схемою, яка наведена в роботі [7]. Для найбільш значущих фракторів будували графрічні залежності (рис. 1-4).

При дослідженні таблеток карбамазепіну з тіотриазоліном на стійкість до роздавлювання на підставі дисперсійного аналізу експериментальних даних встановлено, що вивчені якісні фрактори на вказаний показник можна розмістити в такій послідовності: $A>C>D>B>$ res.

Вплив природи наповнювачів на стійкість таблеток карбамазепіну з тіотриазоліном до роздавлювання зображено на рисунку 1.

3 даних рисунка 1 видно, що найбільш стійкі до роздавлювання таблетки кармазепіну з тіотриазоліном були отримані при використанні в якості наповнювача лактози моногідрату $(99,88$ H), яка має перевагу над цукровою пудрою $(81,15 \mathrm{H})$, МКЦ 101 $(75,73$ Н) і МКЦ $102(59,28$ H).

При дослідженні впливу зв'язуючих розчинів встановлено, що $2 \%$ розчин МЦ 15 дозволяє отримати таблетки карбамазепіну з тіотриазоліном з найбільшою

Таблиця 1. Фактори та їх рівні, які вивчали при створенні таблеток карбамазепіну з тіотриазоліном

\begin{tabular}{|c|l|}
\hline Фактори & \multicolumn{1}{c|}{ Рівні фракторів } \\
\hline А - Наповнювачі & $\mathrm{a}_{1}-$ лактоза моногідрат \\
& $\mathrm{a}_{2}-$ сахароза пудра \\
& $\mathrm{a}_{3}-$ МКЦ 101 \\
& $\mathrm{a}_{4}-$ МКЦ 102 \\
\hline В - Розпушувачі & $\mathrm{b}_{1}-$ крохмаль картопляний \\
& $\mathrm{b}_{2}-$ натрію кроскармелоза \\
& $\mathrm{b}_{3}-$ кросповідон ХЛ 10 \\
& $\mathrm{b}_{4}-$ крохмаль преджелатанізований \\
\hline С - Зв'язуючі & $\mathrm{c}_{1}-2 \%$ крохмальний клейстер \\
& $\mathrm{c}_{2}-2,5 \%$ розчин МЦ 15 \\
& $\mathrm{c}_{3}-5 \%$ розчин пвП \\
& $\mathrm{c}_{4}-2 \%$ розчин ГпМц \\
\hline D - Змазуючі & $\mathrm{d}_{1}-$ магнію стеарат \\
& $\mathrm{d}_{2}-$ кальцію стеарат \\
& $\mathrm{d}_{3}-$ кислота стеаринова \\
& $\mathrm{d}_{4}-$ натрій лаурилсульфат \\
\hline
\end{tabular}

ISSN 2312-0967. Фармацевтичний часопис. 2017. № 3 
Фармацевтична технологія, біофармація, гомеопатія Pharmaceutical technology, biopharmacy, homeopathy

Таблиця 2. Чотирифракторний експеримент на основі 4х4 греко-латинського квадрата та результати дослідження таблеток карбамазепіну тіотриазоліном

\begin{tabular}{|c|c|c|c|c|c|c|c|c|c|c|c|c|}
\hline $\begin{array}{c}\text { № } \\
\text { cepiï }\end{array}$ & A & B & C & $D$ & $y_{4}$ & $y_{4}{ }^{\prime}$ & $y_{5}$ & $y_{5}{ }^{\prime}$ & $y_{6}$ & $y_{6}{ }^{\prime}$ & $y_{7}$ & $y_{7}{ }^{\prime}$ \\
\hline 1 & $\mathrm{a}_{1}$ & $\mathrm{~b}_{1}$ & $\mathrm{c}_{1}$ & $\mathrm{~d}_{1}$ & 81,0 & 85,0 & 0,29 & 0,22 & 12,4 & 14,2 & 5 & 5 \\
\hline 2 & $\mathrm{a}_{1}$ & $\mathrm{~b}_{2}$ & $\mathrm{c}_{2}$ & $\mathrm{~d}_{4}$ & 116,6 & 113,3 & 0,13 & 0,11 & 7,3 & 7,38 & 2 & 2 \\
\hline 3 & $\mathrm{a}_{1}$ & $\mathrm{~b}_{3}$ & $\mathrm{c}_{3}$ & $\mathrm{~d}_{2}$ & 115,3 & 113,0 & 0,15 & 0,13 & 16,0 & 16,2 & 3 & 4 \\
\hline 4 & $\mathrm{a}_{1}$ & $\mathrm{~b}_{4}$ & $\mathrm{c}_{4}$ & $\mathrm{~d}_{3}$ & 87,3 & 87,6 & 0,21 & 0,27 & 15,3 & 14,1 & 5 & 5 \\
\hline 5 & $\mathrm{a}_{2}$ & $\mathrm{~b}_{1}$ & $\mathrm{c}_{2}$ & $\mathrm{~d}_{3}$ & 92,0 & 90,0 & 0,13 & 0,18 & 16,5 & 17,4 & 4 & 5 \\
\hline 6 & $\mathrm{a}_{2}$ & $\mathrm{~b}_{2}$ & $\mathrm{c}_{1}$ & $\mathrm{~d}_{2}$ & 64,3 & 58,3 & 0,26 & 0,33 & 5,2 & 7,4 & 3 & 4 \\
\hline 7 & $\mathrm{a}_{2}$ & $\mathrm{~b}_{3}$ & $\mathrm{c}_{4}$ & $\mathrm{~d}_{4}$ & 108,3 & 112,6 & 0,16 & 0,17 & 14,1 & 18,4 & 4 & 4 \\
\hline 8 & $\mathrm{a}_{2}$ & $\mathrm{~b}_{4}$ & $\mathrm{c}_{3}$ & $\mathrm{~d}_{1}$ & 60,0 & 63,7 & 0,44 & 0,35 & 11,0 & 11,2 & 4 & 5 \\
\hline 9 & $\mathrm{a}_{3}$ & $\mathrm{~b}_{1}$ & $\mathrm{c}_{3}$ & $\mathrm{~d}_{4}$ & 76,3 & 78,3 & 0,14 & 0,18 & 19,3 & 19,4 & 5 & 4 \\
\hline 10 & $\mathrm{a}_{3}$ & $\mathrm{~b}_{2}$ & $\mathrm{c}_{4}$ & $\mathrm{~d}_{1}$ & 82,5 & 87,6 & 0,22 & 0,29 & 6,5 & 7,2 & 3 & 4 \\
\hline 11 & $\mathrm{a}_{3}$ & $\mathrm{~b}_{3}$ & $\mathrm{c}_{1}$ & $\mathrm{~d}_{3}$ & 47,3 & 51,0 & 0,13 & 0,18 & 8,1 & 8,1 & 4 & 4 \\
\hline 12 & $\mathrm{a}_{3}$ & $\mathrm{~b}_{4}$ & $\mathrm{c}_{2}$ & $\mathrm{~d}_{2}$ & 90,6 & 92,3 & 0,13 & 0,19 & 14,3 & 15,0 & 5 & 5 \\
\hline 13 & $\mathrm{a}_{4}$ & $\mathrm{~b}_{1}$ & $\mathrm{c}_{4}$ & $\mathrm{~d}_{2}$ & 58,6 & 64,0 & 0,15 & 0,21 & 25,3 & 27,4 & 5 & 4 \\
\hline 14 & $\mathrm{a}_{4}$ & $\mathrm{~b}_{2}$ & $\mathrm{c}_{3}$ & $\mathrm{~d}_{3}$ & 46,3 & 49,3 & 0,45 & 0,50 & 4,1 & 5,0 & 4 & 4 \\
\hline 15 & $\mathrm{a}_{4}$ & $\mathrm{~b}_{3}$ & $\mathrm{c}_{2}$ & $\mathrm{~d}_{1}$ & 83,3 & 76,6 & 0,26 & 0,19 & 7,1 & 7,5 & 4 & 4 \\
\hline 16 & $\mathrm{a}_{4}$ & $\mathrm{~b}_{4}$ & $\mathrm{c}_{1}$ & $\mathrm{~d}_{4}$ & 48,5 & 51,2 & 0,40 & 0,48 & 14,5 & 15,1 & 4 & 4 \\
\hline
\end{tabular}

Примітки: $\mathrm{y}_{4}$ і у ' - стійкість таблеток до роздавлювання першої і другої серії відповідно, Н;

$\mathrm{y}_{5}$ і $\mathrm{y}_{5}{ }^{\prime}$ - стираність таблеток першої і другої серії відповідно, \%; $\mathrm{y}_{6}$ і $\mathrm{y}_{6}{ }^{\prime}$ - розпадання таблеток першої і другої серії відповідно, хв; $y_{7}$ і $y_{7}^{\prime}$ - зовнішній вигляд поверхні таблеток після шести місяців зберігання першої і другої серії відповідно, бал.

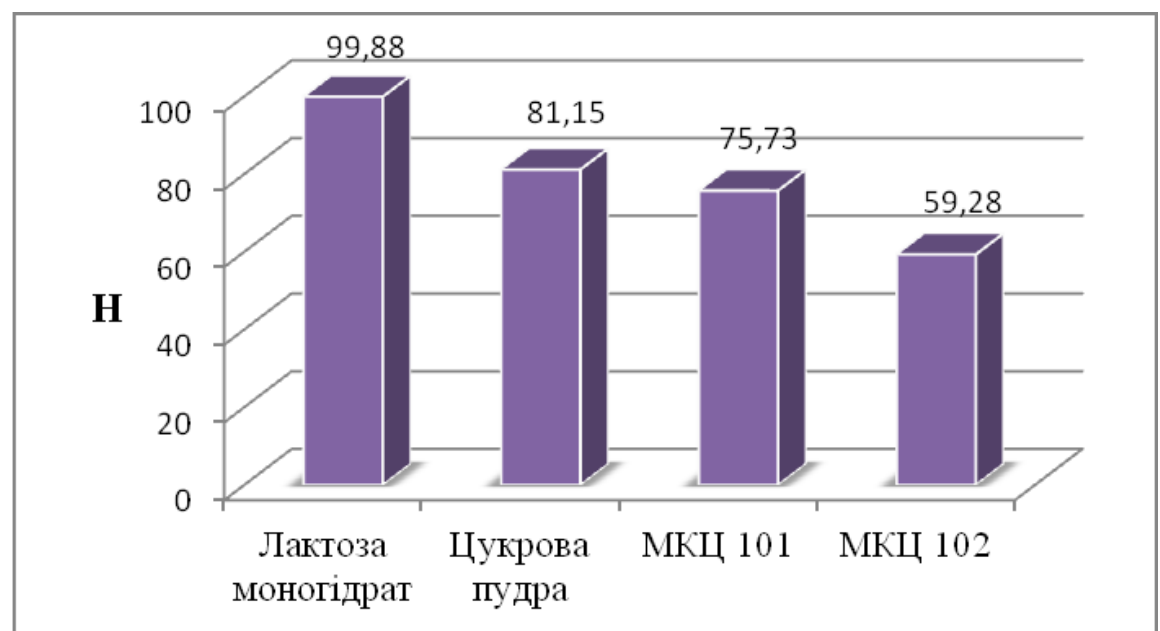

Рис. 1. Вплив природи наповнювачів на стійкість таблеток карбамазепіну з тіотриазоліном до роздавлювання.

стійкістю до роздавлювання (94,33 Н) і має переваги над $2 \%$ розчином ГПМЦ $(86,06 \mathrm{H}), 5$ \% розчином ПВП $(75,27$ Н) та 2 \% крохмальним клейстером $(60,82$ H).

Найбільш стійкі до роздавлювання таблетки карбамазепіну з тіотриазоліном отримували при використанні в якості зв'язуючої речовини (фактор D) натрію лаурилсульсрату $(88,13$ H), який має переваги над кальцію стеаратом (82,05 H), магнію стеаратом $(77,46$ H) і кислотою стеариновою $(68,85$ H).
Найбільш стійкими до роздавлювання отримували таблетки карбамазепіну з тіотриазоліном при використанні кросповідону XL $10(88,42$ H), який має перевагу над крохмалем картопляним $(78,15$ H), натрію кроскармелозою $(77,28$ H) і крохмалем преджелатанізованим $(72,65 \mathrm{H})$.

Первинні результати та значення середніх величин показали, що вдалося отримати таблетки карбамазепіну 3 тіотриазоліном з достатньою стійкістю до роздавлювання.

ISSN 2312-0967. Pharmaceutical review. 2017. № 3 
Фармацевтична технологія, біофармація, гомеопатія Pharmaceutical technology, biopharmacy, homeopathy

Дисперсійний аналіз експериментальних даних показав, що вплив вивчених фракторів на стираність таблеток карбамазепіну з тіотриазоліном можна зобразити наступним рядом переваг: $\mathrm{B}>\mathrm{A}>\mathrm{C}>\mathrm{D}$.

Вплив розпушувачів на стираність таблеток карбамазепіну з тіотриазоліном зображено на рисунку 2.

3 даних рисунка 2 видно, що найменша стираність таблеток карбамазепіну з тіотриазоліном спостерігається при використанні в якості розпушувачів кросповідону ХЛ 10 (0,17 \%) і крохмалю картопляного (0,19 \%). Вказані ДР мають перевагу над натрій кроскармелозою (0,28 \%) і крохмалем преджелатанізованим $(0,31 \%)$.

Найменша стираність таблеток карбамазепіну 3 тіотриазоліном була отримана при використанні МКЦ 101 (0,18 \%) та лактози моногідрату (0,19\%). При використанні цукрової пудри (0,25\%) та МКЦ 102 (0,33 \%) стираність таблеток була більшою.

Найменша стираність таблеток карбамазепіну з тіотриазоліном спостерігається при використанні $2 \%$ розчину МЦ $(0,16 \%)$, який має перевагу над $2 \%$ розчином ГПМЦ $(0,21 \%)$. 2\% крохмальним клейстером $(0,28 \%)$ та 5 \% розчином ПВП (0,29\%).

Найменша стираність таблеток кармазепіну 3 тіотриазоліном спостерігається при використанні кальцію стеарату $(0,19 \%)$, наступні місця займають натрій лаурилсульсрат (0,22 \%), кислота стеаринова $(0,25 \%)$ та магнію стеарат (0,28 \%). Зазначимо, що отримані таблетки кармазепіну 3 тіотриазоліном у всіх серіях дослідів були стійкими до стирання і первинні результати не перевершували 0,50 \%.

Дисперсійний аналіз експериментальних даних показав, що вплив вивчених фракторів на час розпа- дання таблеток карбамазепіну з тіотриазоліном можна зобразити таким рядом переваг: $\mathrm{B}>\mathrm{D}$ > C > res при статистичній незначущості фрактора A.

Вплив розпушувачів на розпадання таблеток карбамазепіну з тіотриазоліном зображено на рисунку 3.

Порівняння середніх значень рівнів фрактора В показало, що найшвидше розпадалися таблетки кармазепіну з тіотриазоліном при використанні в якості розпушувача натрію кроскармелози (6,3 хв). Вказаний розпушувач має суттєву перевагу над кросповідоном ХЛ 10 (11,9 хв), крохмалем преджелатанізованим (13,8 хв) та крохмалем картопляним (18,9 хв). Зауважимо, що тільки при використанні в якості розпушувача крохмалю картопляного середнє значення часу розпадання таблеток перевершувало вимоги ДФ України (більше 15 хв).

Найменше значення часу розпадання таблеток карбамазепіну з тіотриазоліном отримували при використанні магнію стеарату (9,8 хв), який має перевагу над кислотою стеариновою (11,5 хв), натрію лаурилсульфатом $(14,4$ хв) та кальцію стеаратом (15,8 хв).

Таблетки карбамазепіну з тіотриазоліном оцінювали на зміну зовнішнього вигляду після 6-ти місяців зберігання. Встановлено, що на цей показник впливають такі фрактори: $\mathrm{B}$ > res > D при статистичній незначущості фракторів А і С. На відміну від результату оцінки поверхні таблеток карбамазепіну з тіотриазоліном після виготовлення таблеток, коли статистично значущим виявилася тільки природа розпушувачів.

Вплив розпушувачів на зовнішній вигляд таблеток карбамазепіну з тіотриазоліном зображено на рисунку 4.

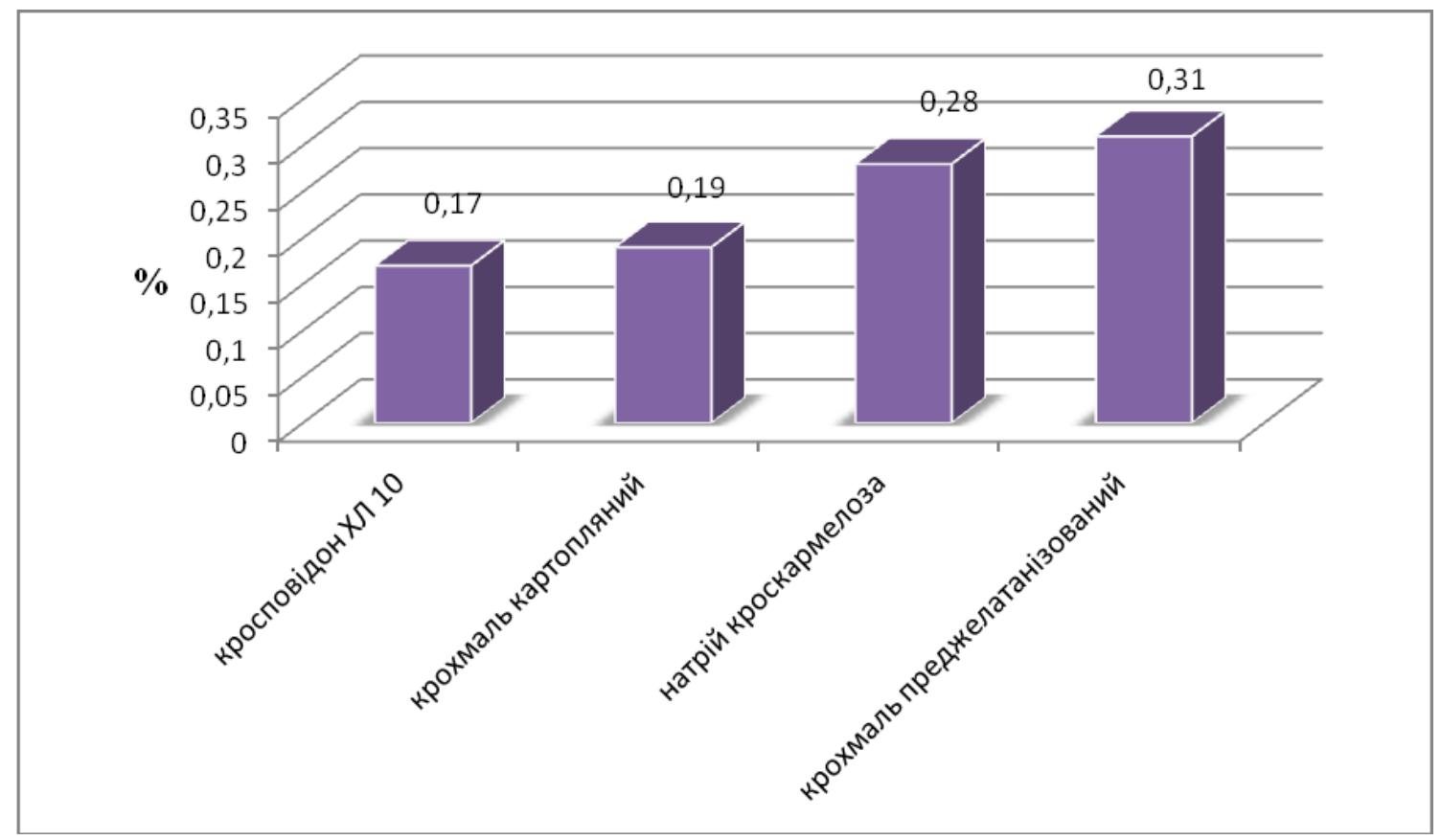

Рис. 2. Вплив розпушувачів на стираність таблеток карбамазепіну з тіотриазоліном.

ISSN 2312-0967. Фармацевтичний часопис. 2017. № 3 
Фармацевтична технологія, біофармація, гомеопатія Pharmaceutical technology, biopharmacy, homeopathy

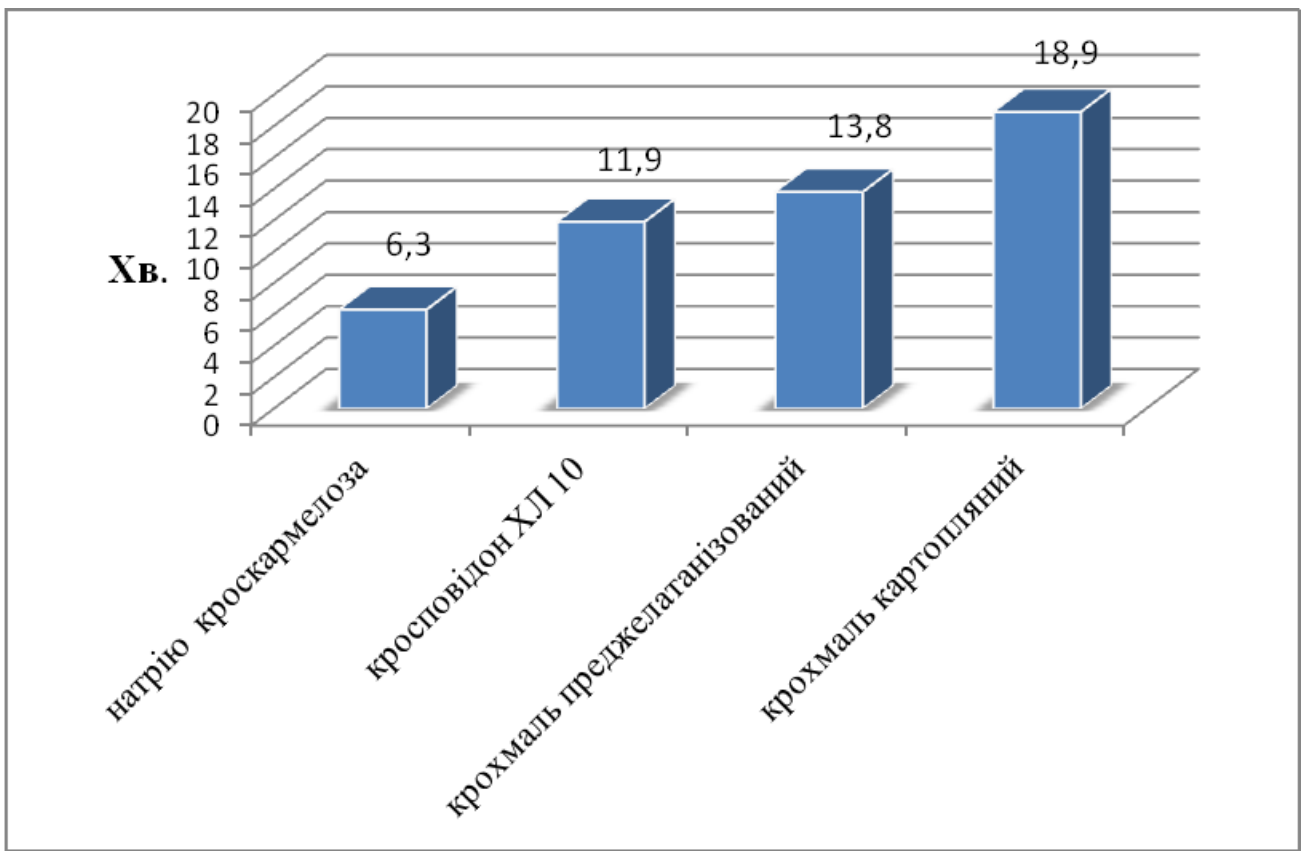

Рис. 3. Вплив розпушувачів на розпадання таблеток карбамазепіну з тіотриазоліном.

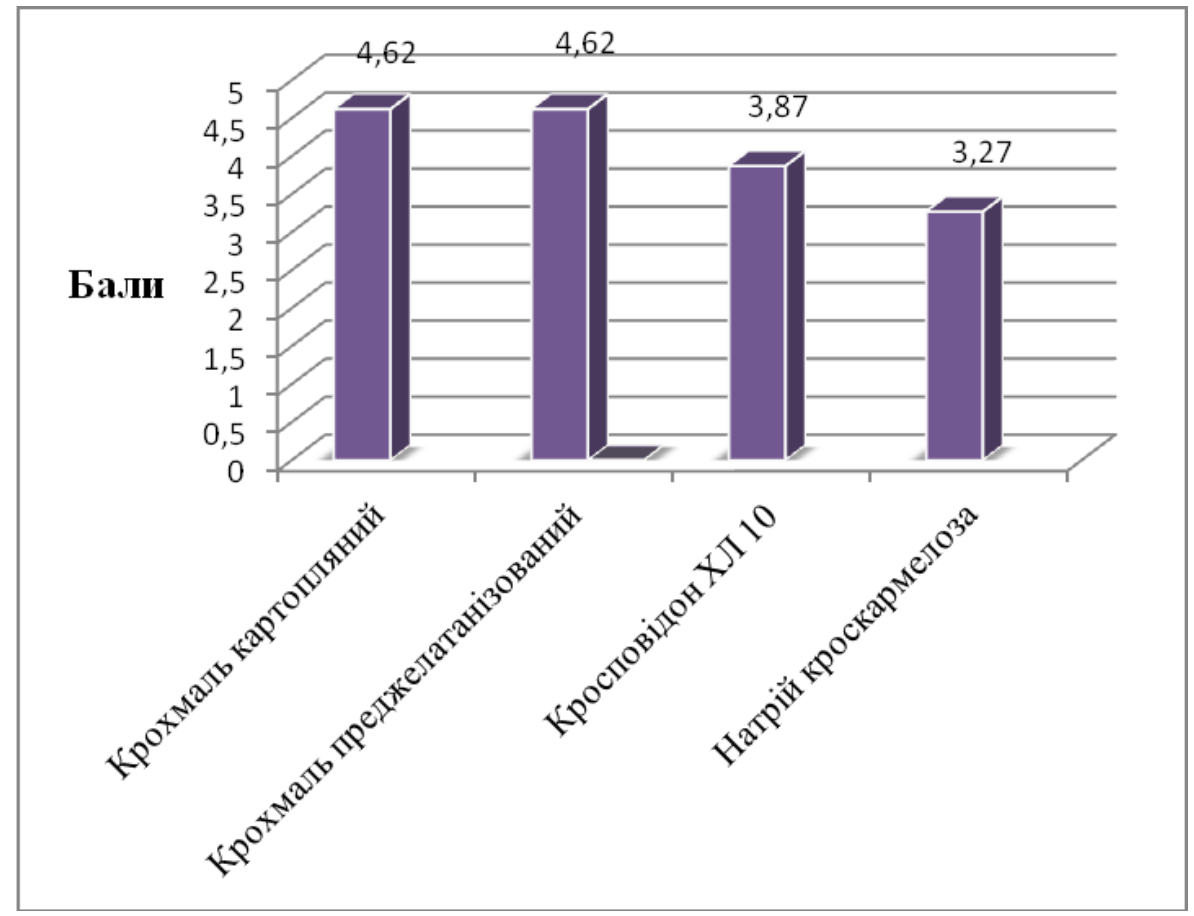

Рис. 4. Вплив природи розпушувачів на зовнішній вигляд таблеток карбамазепіну з тіотриазоліном після 6-ти місяців зберігання.

Ефективність розпушувачів за впливом на якість поверхні таблеток карбамазепіну 3 тіотриазоліном можна зобразити таким рядом переваг: крохмаль картопляний (4,62 бали) > крохмаль преджелатанізований (4,62 бала) > кросповідон ХЛ 10 (3,87 бала) > натрій кроскармелоза (3,27 бала). Зауважимо, що при використанні крохмалю картопляного і крохмалю преджелатанізованого зовнішній вигляд таблеток карбамазепіну з тіотриазоліном майже не змінився, тоді як при використанні кросповідону ХЛ 10 і натрій кроскармелози якість поверхні таблеток після 6-ти місячного зберігання зменшилась на 0,63 і 0,73 бала відповідно.

Найкращу якість поверхні таблеток карбамазепіну 3 тіотриазоліном після 6-ти місяців зберігання забезпечує кислота стеаринова (4,37 бала), якій дещо по-

ISSN 2312-0967. Pharmaceutical review. 2017. № 3 
Фармацевтична технологія, біофармація, гомеопатія Pharmaceutical technology, biopharmacy, homeopathy

ступається кальцію стеарат (4,25 бала), магнію стеарат (4,12 бала) і суттєво поступається натрій лаурилсульфрат (3,22 бала).

Проведені дослідження дозволили вивчити вплив основних груп допоміжних речовин, які найчастіше використовуються при створенні таблеток методом вологої грануляції. За дослідженням фрармако-технологічних показників отримані позитивні результати, щодо більшості із вивчених допоміжних речовин.

При виборі раціональних ДР брали до відома результати досліджень, які відображені в попередньому повідомленні [4], а також отримані в цих дослідженнях. Серед вивчених наповнювачів найкращім раціонально вважати МКЦ 101, за допомогою якого забезпечується найкращий процес пресування $\left(\mathrm{y}_{1}\right)$, однорідність маси таблеток карбамазепіну з тіотриазоліном $\left(\mathrm{y}_{3}\right)$ та стійкість до стирання $\left(\mathrm{y}_{5}\right)$. Заслуговує на увагу також лактоза моногідрат, за допомогою якої забезпечується найбільша стійкість таблеток до роздавлювання $\left(\mathrm{y}_{4}\right)$.

Серед вивчених розпушувачів слід виключити 3 подальших досліджень кросповідон ХЛ 10 та натрій кроскармелозу. За допомогою вказаних ДР отримували таблетки карбамазепіну 3 тіотриазлоліном 3 найменшим часом розпадання, однак зміна кольору поверхні таблеток (від білого до ледь жовтуватого), а також зменшення кількості діючих речовин у процесі зберігання таблеток спонукало нас вилучити вказані
ДР. Заслуговує на увагу вивчення кількості крохмалю преджелатанізованого та крохмалю картопляного в складі таблеток карбамазепіну з тіотриазоліном.

Серед вивчених зв'язуючих розчинів немає вираө женого «лідера» за всіма фрармако-технологічними показниками таблеток карбамазепіну 3 тіотриазоліном. Встановлено, що найбільш однорідна та гомогенна таблеткова маса виходила при використанні розчину ПВП. Заслуговує також на увагу розчин МЦ 15. Серед змазуючих речовин для подальших досліджень відібраний кальцію стеарат.

Вказані ДР підлягали більш детальному дослідженню при розробці оптимального складу і технології таблеток карбамазепіну з тіотриазоліном. В результаті дослідження для отримання раціонального складу таблеток «Карбатрил» треба використовувати такі ДР: МКЦ 101, крохмаль картопляний, ПВП, кальцію стеарат.

Висновки. Вивчено вплив 16-ти допоміжних речовин на фрармако-технологічні властивості (стійкість до роздавлювання, стираність, розпадання, зовнішній вигляд поверхні після 6-ти місяців зберігання) таблеток карбамазепіну з тіотриазоліном. За сукупністю вивчених показників відібрані кращі поєднання ДР для подальшого вивчення 3 метою розробки оптимального складу та технології таблеток кармазепіну з тіотриазоліном.

\title{
ВЫБОР ВСПОМОГАТЕЛЬНЫХ ВЕЩЕСТВ С ЦЕЛЬЮ ПОЛУЧЕНИЯ ТАБЛЕТОК НА ОСНОВЕ КАРБАМАЗЕПИНА И ТИОТРИАЗОЛИНА МЕТОДОМ ВЛАЖНОЙ ГРАНУЛЯЦИИ
}

\author{
Л. И. Кучеренко ${ }^{1,2}$, А. Р. Нименкоㄹ, З. Б. Моряк ${ }^{1,2}$ \\ НПО «Фарматрон» ${ }^{1}$ \\ Запорожский государственный медицинский университет² \\ farm_chem@bigmir.net
}

Цель работы. Изучение влияния вспомогательных веществ (ВВ) на фрармако-технологические показатели таблеток карбамазепина с тиотриазолином, полученных методом влажной грануляции. Выбор лучших ВВ для получения оптимального состава таблеток карбамазепина с тиотриазолином.

Материалы и методы. Действующие вещества - карбамазепин с тиотриазолином (1,5:1), вспомогательные вещества (наполнители, разрыхлители, связывающие, смазывающие). Таблетки прессовали методом влажной грануляции. Влияние вспомогательных веществ на таблетки изучали по следующим показателям: стойкость к раздавливанию, стираемость, распадаемость, внешний вид поверхности после 6-месячного хранения.

Результаты и обсуждение. По результатам дисперсионного анализа экспериментальных данных было установлено, что на стойкость таблеток карбамазепина с тиотриазолином к раздавливанию, стираемости, распадаемости, внешнему виду поверхности после 6-месячного хранения влияет природа наполнителя, разрыхлителя, связывающих и смазывающих ВВ. Так на стойкость таблеток к раздавливанию среди наполнителей лучшее влияние проявляет - лактоза моногидрат, среди разрыхлителей лидером является - кросповидон ХЛ 10 , среди связывающих - 2 \% раствор МЦ, среди смазывающих веществ - натрий лаурилсульфат.

Наименьшая стираемость таблеток карбамазепина с тиориазолином наблюдалась при использовании в качестве наполнителя - МКЦ 101, разрыхлителя - кросповидона ХЛ 10, связывающих - 2 \% раствор МЦ, смазывающих кальция стеарат.

Быстрее всего распадались таблетки карбамазепина с тиотриазолином при использовании в качестве разрыхлителя - натрия кроскармелозы, смазывающего вещества - магния стеарата и связывающего вещества - крахмального клейстера. Наполнители не отличались между собой по влиянию на время распадания таблеток карбамазепина с тиотриазолином.

ISSN 2312-0967. Фармацевтичний часопис. 2017. № 3 
Крахмал картофельный и кислота стеариновая в наибольшей мере обеспечивают сохранение цвета поверхности таблеток карбамазепина с тиотриазолином после 6-ти месяцев хранения. Изученные наполнители и связывающие вещества в одинаковой мере влияют на указанный показатель.

Выводы. Изучено влияние 16-ти вспомогательных веществ на фрармако-технологические свойства (стойкость к раздавливанию, стираемость, распадаемость, внешний вид поверхности после 6-ти месяцев хранения) таблеток карбамазепина с тиотриазолином. По совокупности изученных показателей отобраны лучшие сочетания ВВ для дальнейшего изучения с целью разработки оптимального состава и технологии таблеток карбамазепина с тиотриазолином.

Ключевые слова: карбамазепин; тиотриазолин; таблетки; вспомогательные вещества; метод влажной грануляции; математическое планирование эксперимента.

\title{
EXCIPIENTS CHOICE TO OBTAIN TABLETS BASED ON CARBAMAZEPINE AND THIOTRIAZOLINE BY WET GRANULATION METHOD
}

\author{
L. I. Kucherenko ${ }^{1,2}$, G. R. Nimenko², Z.B. Moryak ${ }^{1,2}$ \\ SPA «Farmatron» ${ }^{1}$, \\ Zaporizhzhia State Medical University² \\ farm_chem@bigmir.net
}

The aim of the work. Studying the influence of excipients on the pharmaco-technological parameters of carbamazepine tablets with thiotriazoline, obtained by the wet granulation method. Choosing the best excipients to get the optimal composition of pills with the thiotriazoline.

Materials and Methods. Medicinal substances - carbamazepine and thiotriazoline (1.5: 1), excipients (fillers, extenders, binders, lubricants). The tablets were made by wet granulation method. The influence of excipients on carbamazepine tablets with thiotriazoline was studied according to the following indices: resistance to crushing, erosion, decomposition, appearance of the surface after 6 months of storage.

Results and Discussion. According to the results of the dispersion analysis of experimental data, it has been established that the nature of the filler, binder, binder and lubricating excipients affects the stability of the tablets of carbamazepine with thiotriazolin to crushing, erosion, disintegration, appearance of the surface after 6 months of storage. Thus, lactose monohydrate has the best effect on the stability of the tablets for crushing among the fillers; the crossover chloride is among the chemists, among the binders is a $2 \%$ solution of $\mathrm{MC}$, among the lubricants is sodium laurylsulfate.

The slightest erosion of carbamazepine tablets with thiotriazolin is observed when used as a filler of MCC 101, a rupture agent - Crospovidone CL 10 binding - $2 \%$ solution of MC, lubricating - calcium stearate.

The most rapid disintegration of pills of carbamazepine with thiotriazoline was used when sodium croscarmellose was used as lubricant, magnesium stearate and binding substances - starch paste. Fillers do not differ in their effects on the time of disintegration of tablets of carbamazepine with thiotriazolin.

The potato starch and stearin acid provide the highest level of preservation of the surface color of the tablets of carbamazepine with thiotriazoline after 6 months of storage. Investigated fillers and binders to the same extent affect the indicated index.

Conclusions. The influence of 16 excipients on the pharmaco-technological properties (resistance to crushing, erosion, decomposition, appearance of the surface after 6 months of storage) of carbamazepine tablets with thiotriazolin was studied. According to the aggregate of the studied indices, the best combination of excipients for further study was selected in order to develop the optimal composition and technology of tablets of carbamazepine with thiotriazolin.

Key words: carbamazepine; thiotriazolin; tablets; excipients; wet granulation method; mathematical experiment planning.

\section{Список літератури}

1. Підвищення ефективності лікування епілепсії / л. І. Кучеренко, І. Ф. Бєленічев, В. Й. Мамчур [та ін.] // (Інфрорм. лист про нововведення в системі охорони здоров'я / Укрмедпатентінорорм; Вип. 19 з проблеми «Фармація») - 2015. - № 225-2015. - С. 4.

2. Разработка лекарственных средств на основе фриксированных комбинаций с антиоксидантами - перспективное направление современной фрармакологии / И. А. Мазур, И. С. Чекман, И. Ф. Беленичев [и др.] //
Фармакологія та лікарська токсикологія. - 2011. - № 5. - C. 199-200.

3. Park S. P. Cognitive effects of antiepileptic drugs / S. P. Park, S. H. Know // J. Clin. Neurol. - 2008. - № 4. P. 99-106.

4. Кучеренко Л. І. Вибір допоміжних речовин з метою отримання таблеток на основі карбамазепіну з тіотриазоліном методом вологої грануляції. Повідомлення 1. Вплив допоміжних речовин на процес пресування,

ISSN 2312-0967. Pharmaceutical review. 2017. № 3 
Фармацевтична технологія, біофармація, гомеопатія Pharmaceutical technology, biopharmacy, homeopathy

якість поверхні та однорідність дозування таблеток карбамазепіну з тіотриазоліном, отриманих методом вологої грануляції / Л. І. Кучеренко, Г. Р. Німенко, З. Б. Моряк // Фармацевтичний часопис. - 2017. - № 2. - С. 52-58.

5. Допоміжні речовини в технології ліків: вплив на технологічні, споживчі, економічні характеристики і терапевтичну ефективність / [І. М Перцев, Д. І. Дмитрієвський, О. П. Гудзенко та ін.]. - Харків : Золоті сторінки, 2010. -600 c.

\section{References}

1. Kucherenko LI, Bielenichev IF, Mamchur VY, Opryshko VI, Portna OO, Nimenko HR. Improved treatment of epilepsy, №225-2015, Vyp. 19 z problemy «Farmatsiia». (Informatsiynyi lyst). Ukrainian.

2. Mazur IA, Chekman IS, Belenichev IF, Kucherenko LI. [Development of drugs based on fixed combinations with antioxidants is a promising area of modern pharmacology] Farmakol and likar toxicol. 2011;5:199-200.

3. Park SP, Know SH. Cognitive effects of antiepileptic drugs. J Clin Neurol. 2008;4: 99-6.

4. Kucherenko LI, NimenkoAR, Moryak ZB. [Excipients choice to obtain tablets based on carbamazepine and thiotriazolin by method of wet granulation]. Farmatsevt chasop. 2017;2: 52-8. Ukrainian.
6. Державна Фармакопея України: в 3 т. / Державне підприємство «Український науковий срармакопейний центр якості лікарських засобів». - 2-е вид. - Харків : Державне підприємство «Український науковий фрармакопейний центр якості лікарських засобів», 2015. - Т. 1. - 1128 с.

7. Математичне планування експерименту при проведенні наукових досліджень в фрармації / Т. А. Грошовий, В. П. Марценюк, Л. І. Кучеренко та ін.]. - Тернопіль : Укрмедкнига, 2008. - 367 с.

5. Pertsev IM, Dmytrievskyi DI, Hudzenko OP. Excipients in drug technology: influence on technological, consumer, economical characteristics and therapeutic effectiveness. [Допоміжні речовини в технології ліків: вплив на технологічні, споживчі, економічні характеристики і терапевтичну ефективність] Kharkiv: National University of Pharmacy; 2010. Ukrainian.

6. State Pharmacopoeia of Ukraine. [Державна Фармакопея України: в 3 т., 2-е вид.] Kharkiv: Derzhavne pidpryiemstvo «Naukovo-ekspertnyi farmakopeinyi tsentr»; 2015. Ukrainian.

7. Hroshovyi TA, Martsenyuk VP, Kucherenko LI, Vronska LV, Huryeyeva CM. Mathematical planning of experiment in pharmacy. [Математичне планування експерименту в орармації] Ternopil: Ternopil State Medical University; 2008. Ukrainian

Отримано 03.07.2017

ISSN 2312-0967. Фармацевтичний часопис. 2017. № 3 